\title{
The dynamics of stiff clubmoss Lycopodium annotinum $L$. patches in clumps of trees left on the clear-cutting in pine forest Leucobryo-Pinetum
}

\author{
Monika Bogdanowicz ${ }^{1}$, Anna Śliwińska-Wyrzychowska ${ }^{1} \bowtie$, Anna Świercz ${ }^{2}$, \\ Marcin Kiedrzyński \\ ${ }^{1}$ Jan Długosz University in Częstochowa, The Faculty of Mathematics and Natural Sciences, Department of Botany \\ and Plant Ecology, Armii Krajowej 13/15, 42-200 Częstochowa, Poland, phone: 505599857, \\ e-mail: a.wyrzychowska@gmail.com \\ 2 The Jan Kochanowski University in Kielce, The Faculty of Mathematics and Natural Science, Department of Soil \\ and Culture Landscape Protection, Świętokrzyska 15, 25-506 Kielce, Poland \\ ${ }^{3}$ University of Łódź, Faculty of Biology and Environmental Protection, Department of Geobotany and Plant Ecology, \\ Banacha 12/16, 90-237 Łódź, Poland
}

\section{Abstract}

Clumps of trees left on the clear-cuttings have an important role in protecting populations of endangered plant species against destruction during silviculture activities. The aim of this study is to describe the changes in the area of the Lycopodium annotinum patches. The area of L. annotinum patch in clump of trees, have been significantly reduced during 5 years after clear-cut. In the first year of the observations, the studied population occupied an area of $69.8 \mathrm{~m}^{2}$ whereas in 2012, it was only $37.5 \mathrm{~m}^{2}$. Most of the shoots were withered away on the south side of the clump. The probable reason was too strong insolation. Shoots that survived were located in the north part of the clump - shielded by young trees and shrubs layer. At this time, the control patch of L. annotinum located inside the forest increased its area. Before the clear-cuttings, the annual growth of vertical shoots of clubmoss was higher in the patch located in future tree clump. After the clear-cutting, growth of shoots in this patch was shorter than in patch located all the time inside the forests. The most effective growth was observed in the third studied patch located in the clearcutting border. The explanation for this phenomenon could be the higher humidity of habitat on this site. Clumps of trees left after the clear-cutting contribute to the protection of endangered populations, but do not eliminate the significant microhabitat changes. The clubmoss patches located in moist habitats are more likely to survive even if they are partially exposed to the sunlight.

\section{KeY WORDS}

clubmoss, insolation, humidity, stems, clear-cutting 


\section{INTRODUCTION}

All species of clubmosses that can be found in Poland are covered by species protection; however, the regulation concerning the protection allows some exceptions to it (Rozporządzenie 2014). Thus, it is permissible to destroy the stands of protected species during silviculture activities. Clear-cuttings are one of the most dangerous treatments for clubmosses and other plants occurring in coniferous habitats, for example, Chimaphila umbellata, Pyrola chlorantha and Pulsatilla patens (Sokołowski and Paluch 2006). Clear-cuttings dramatically change the existing habitat, leading to the direct or indirect disappearance of stands of these plants. Due to an extended development cycle (lasting up to several years) (Grochowski 1956; Piękoś-Mirkowa and Mirek 2003) and greatly changed microhabitat conditions after the clear-cutting, the regeneration of clubmoss populations is meaningfully hindered. This phenomenon is more and more frequent in Poland (Kurkowski 2000). The way to preserve clubmoss stands (also facilitating the regeneration of the forest) is to leave a fragment of tree stand with undisturbed soil and vegetation in the area of a clear-cutting (Sokolowski 2004; Gorzelak 2009; Obidziński 2001).

This work is an attempt to answer the questions: how do clubmoss populations behave (area of the Lycopodium annotinum patch, length of the increments on the vertical stems and the density of live stems in the patch), when they are left within a clump of trees on the clear-cutting (compared to undisturbed patches), and is this method of management a real chance for survival of this group of plants in commercial forests? For the study, there were selected patches of stiff clubmoss Lycopodium annotinum L. This species is characterised by a fairly significant growth of creeping stems during the year (on average, even more than 6 $\mathrm{cm}$ ), which facilitates observing its dynamics - growth or regression in different microhabitat conditions (Svensson and Callaghan 1988a, b).

\section{MATERIAL AND MEthOdS}

The study was conducted in 2008-2012 on three stands located in Złoty Potok forest district in the border area between the Włoszczowska syncline and
Częstochowska upland. The first stand was in a clump of Pinus sylvestris left on a clearcutting, conducted in 2008. Area of the clump of Pinus sylvestris was about $650 \mathrm{~m}^{2}$. The distance from the clump to the nearest adjacent woodland was $28 \mathrm{~m}$. The second stand was $200 \mathrm{~m}$ away in an area in which no forestry works were conducted. Both stands were in the fresh coniferous forest (Leucobryo-Pinetum). The third stand was located in moist coniferous forest (Molinio caeruleaePinetum) in an intact tree stand on the border of the clear-cutting (Report 1996-2005). On all stands, there was measured the size of L. annotinum patch in four basic geographical directions and four intermediate directions from the indicative centre of the patch. The aim of the measurement was to calculate the surface area occupied by the stems and to determine changes in their cover in consecutive years of the study. In 2008, on the first stand in the greatest density of L. annotinum vegetative stems, there were set up two research squares of $1 \times 1 \mathrm{~m}$. Within each square, every year, there were conducted floristic inventories with an estimated cover of each species (scale 1, 5, 10, 15..., 100\%). In the same year, on the second stand, there was set up one research square. The difference in the number of squares resulted from the size of the clubmoss patches. On the third stand, there was marked a transect consisting of 12 contiguous squares of $1 \times 1 \mathrm{~m}$. The transect ran from the clear-cutting to the stand in the intact forest. Within each square, in 2008 and 2012, the floristic inventories by using the same method as mentioned above were performed. In 2009, on all three stands, there were randomly selected 30 living, vertical stems of L. annotinum and there was measured the length of their increments. The single increment was a length between two narrowings on the stem (fig.1). Every new narrowing was being formed at the end of each growing season. Presence of the narrowings enabled to specify the length of the increment on the vertical stem. Length of yearly increment was measured in the next year (in 2009 , it was possible to measure the length of increment from 2008; in 2010 - from 2009, etc.) to show the differences between the size of vertical stem. In order to verify the significance of differences between the lengths of the vertical stem increments in the following years, on each of the stands there were conducted: the Kruskal-Wallis test, median test and the test of multiple comparisons of mean ranks (2-tailed). 


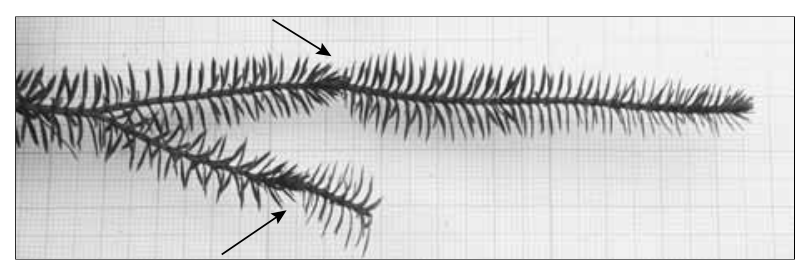

Figure 1. Narrowing on the vertical stem of Lycopodium annotinum

In order to characterise the general habitat conditions in 2010, there were carried out floristic inventories with estimated undergrowth cover on the surface of $20 \times 20 \mathrm{~m}$ (scale 1, 5, 10, 15.., 100\%). On this basis, using Ellenberg's indicator values (Ellenberg 1991; Kimsa 1996), the degree of humidity, insolation and mineral nitrogen compounds of the habitat was determined. Data were analysed using the weighted average method (with the value of the species coverage as weight) and the unweighted average one (all present species had the same weight).

\section{Results}

Patch dimensions of clubmoss growing on the first stand, underwent significant changes from 2008 to 2012 (fig. 2). In 2008, the surface of the patch was $69.8 \mathrm{~m}^{2}$

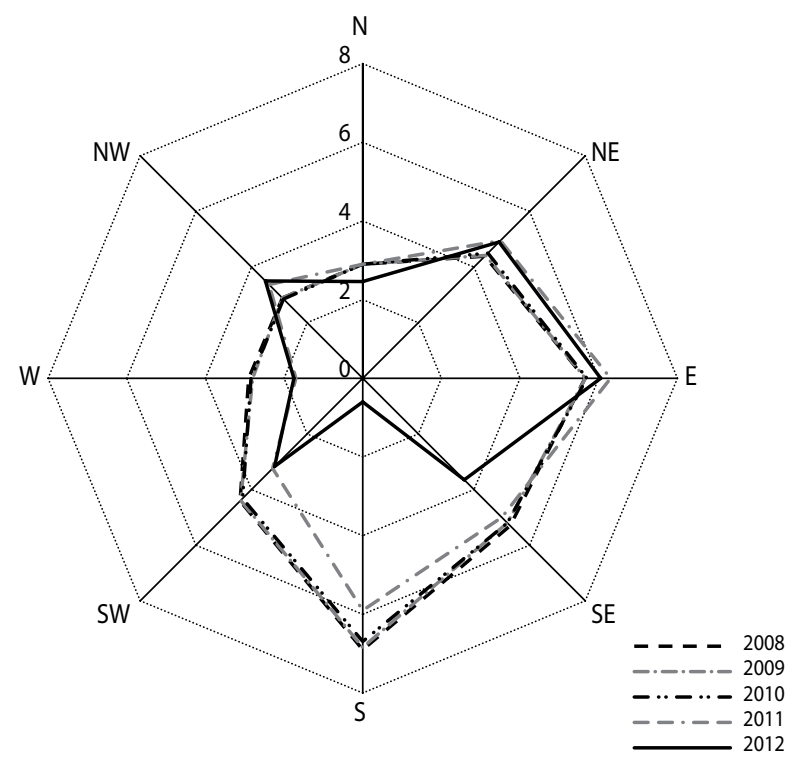

Figure 2. Changes of Lycopodium annotinum patch growing in a clump of trees on the clear-cutting in 2008-2012 (stand 1) while in 2012 , only $37.5 \mathrm{~m}^{2}$ (a decrease by $46 \%$ ). The range of $L$. annotinum stems decreased from the south, south-east, south-west and west sides. From the east and north-east sides, these changes were insignificant. A slight increase of the stem range was observed from the north-west side. Changes of L. annotinum stem range on the second stand (fig. 3) were smaller than that on the first stand. Here there was observed the increase of the range of stems primarily in south-west, west, north-west and north-east directions. Only in the southeast direction, there was observed the slight decrease. In 2008, the size of the area occupied by clubmossstems was $19.5 \mathrm{~m}^{2}$ but in 2012, it had increased to $24.3 \mathrm{~m}^{2}$ (an increase by $25 \%$ ).

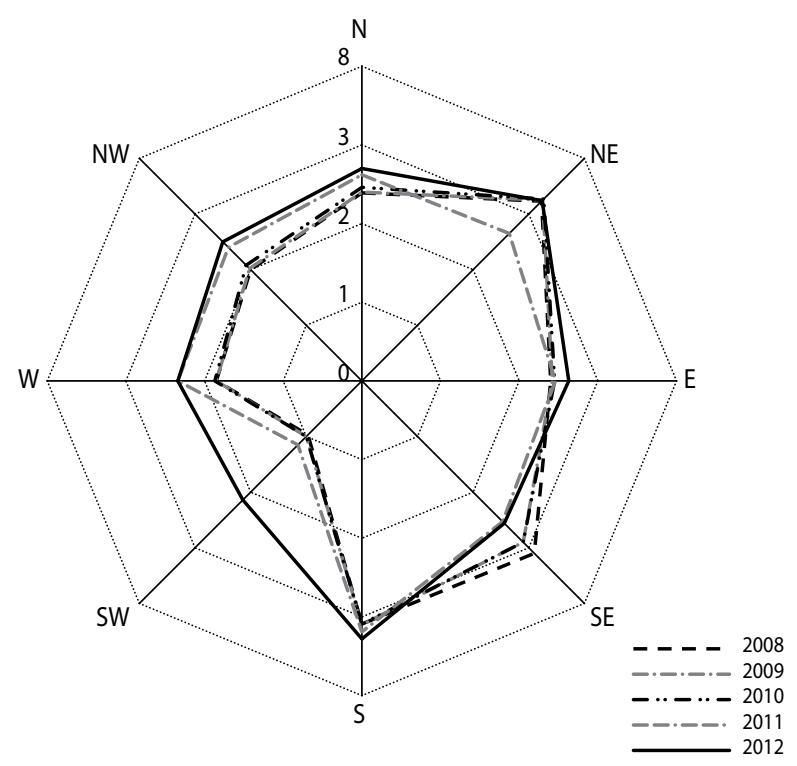

Figure 3. Changes of Lycopodium annotinum patch size deep in the forest in 2008-2012 (stand 2, the control one)

Before carrying out the clear-cutting, in 2008, increments of $L$. annotinum vertical stems on the first stand were about $46.5 \mathrm{~mm}$ on average and they were higher compared to the patch on the second stand -39.6 $\mathrm{mm}$. A year (in 2009) and 2 years (in 2010) after the clear-cutting, the length of increments was higher in the vertical stems on the second stand $(41.0$ and $62.6 \mathrm{~mm}$, respectively), compared to the first stand (increments: 36.2 and $56.8 \mathrm{~mm}$ ). The patch on the third stand each year (2008, 2009 and 2011) was characterised by a greater average length of vertical stem increments compared to the others $(73.1,78.1$ and $109.1 \mathrm{~mm}$, 
respectively). It was also observed that, compared to the year 2011, the length of increments on all the three stands was smaller in previous years. On the first stand, in 2009 , increments were $36 \%$ smaller than in 2011 ; on the second stand, $35 \%$ smaller; on the third stand, $28 \%$ smaller. The analysis of the significance of differences in length of vertical stem increments on the stands one, two and three in subsequent years, showed statistically significant differences between the length of increments in 2011 and in 2008 and 2009 (level of significance $\mathrm{p}<0.01)$.

In 2008, on the first stand, the percentage coverage of undergrowth was $80 \%$ (square 1), $90 \%$ (square 2) and on the second stand $-55 \%$; in $2012-20,15$ and 30 , respectively. The decrease of undergrowth cover was observed on the first stand -75 and $85 \%$ and on the second stand $-45 \%$. There was also observed the decrease of live clubmoss stem cover. On the first stand (in the test squares), in 2012, all stems were found dead, contrary to the second stand. On the third stand, clubmoss cover differs depending on the distance from the border of the clear-cutting. In 2012, in the squares closest to the clear-cutting (squares 1-8), L. annotinum cover got smaller (squares 2-3, 5-7). In the squares situated deeper in the forest (9-12), clubmoss cover increased (fig. 4). In the transect, there were also observed changes in the undergrowth species cover. In 2012, in the first four squares, there was noted very intense increase of the cover - up to $80 \%$ compared to 2008.

The ecological indicator value of humidity, calculated using the weighted average method, did not differ for the stands one and two and amounted to 4.7 (intermediate habitats between dry and fresh ones), and

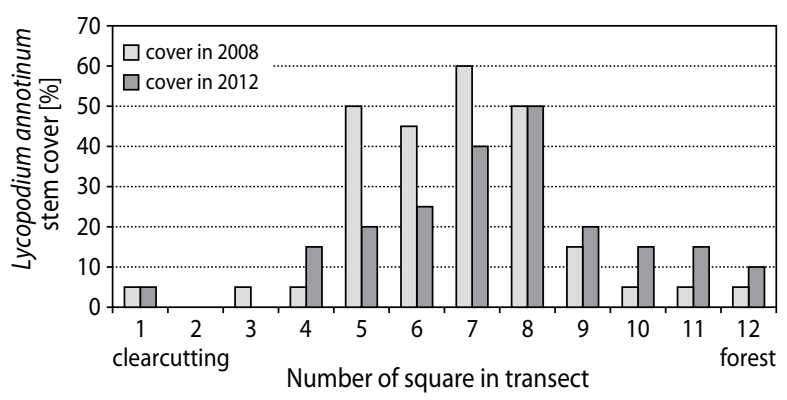

Figure 4. Changes of Lycopodium annotinum stem cover in the transect on the border of clear-cutting in 2008 and 2012 (stand 3) for the third stand, amounted to 6.7 (habitats intermediate between fresh and moist ones). The analysis using the method of unweighted average values showed that the habitat of the first stand has traits intermediate between the dry and fresh one (4.5); of the second stand, traits of fresh habitat (5.1); of the third stand, traits intermediate between the fresh and moist one (6.3). The ecological indicator value of light in all stands indicates the habitats with plants living in half-shadow and exceptionally in full light. The results were almost the same using two different methods - unwegihted (first stand: 5.6; second stand: 5.4; third stand: 5.5) and weighted average (5.6; 5.6; 5.6, respectively). The mineral nitrogen compounds value was very similar for all stands. Using weighted average method, the values of this indicator were: 2.8 (first stand); 2.6 (second stand); 2.6 (third stand). These values indicate soils extremely poor in mineral nitrogen compounds. Using unweighted average method, the third stand had higher value of mineral nitrogen compounds (3.2) compared to the first and second stands where these values (2.7 and 2.8 , respectively) indicate soils poor in mineral nitrogen compound.

\section{Discussion}

The difficulty of the current research was to find clubmoss stands located in the area of existing or planned clear-cuttings. This is due to the overall small number of clubmoss stands in the research area. Additionally, all of them were localised in commercial forests in which the cutting age is about $80-100$ years (the cutting age determines the lifetime of lycopodium patches). Long-term use of forests has caused a number of changes in the species composition of phytocoenoses and in vegetation structure, which have been described as phases and forms of degeneration (Faliński 1966; Olaczek 1972). The pace of regeneration of vegetation after clear-cutting depends on the type of habitat, the level of its transformation and the state of species conservation relevant to the given phytocenoses (Laska 2001; Kurowski 2004). Sokołowski's and Sokołowski and Paluch's long-term observations (2004, 2006) suggest that changes in vegetation structure caused by clear-cutting and artificial regeneration of forest are usually minor and transient. The authors found no qualitative and quantitative differences in the species 
composition and structure of young forest and old growth of trees. But they point out the necessity of leaving some area with intact soil and undergrowth on the clear-cutting, which facilitates the regeneration of many plant populations, including protected species.

Clumps of trees on the clear-cutting become the basis of propagules, so that it speeds up the renewal and regeneration of biocoenosis (Sławski, 2009). In case of L. annotinum, it is more likely to renew or increase the acreage of an existing population through the vegetative growth of stems. It can occur only when the left clump of trees fully covers a patch of the protected species. However, even in the left parts of the tree stand, the conditions are different from the ones that used to be before the clear-cutting. These changes can be a stress factor for all plants growing in the clump of the trees, including L. annotinum. All changes of a microhabitat in the clump of trees, resulting from the exposure, favour the occurrence of new species or the increase of the number of existing ones, which can be competitive against $L$. annotinum.

The observed changes in $L$. annotinum patch growing in a clump of trees on the clear-cutting are probably a response to increased evaporation because Lycopodium clearly reduced its acreage of occurrence in a place of the highest insolation. The part of the patch that was in shadow under the canopy of trees was in better condition- vegetative stems produced new increments every year. This phenomenon can be explained by the strategies used by clubmosses - an opportunistic escape caused by a microhabitat and tactics of a favourable habitat 'seeker' (Callaghan et al. 1986a, b; Svensson and Callaghan 1988). Within a polycormon, there may have taken place the change of direction of nutrients and water transport. Dying stems are not provided with nutrients in favour of those parts of polycormon that occur in more favourable habitats.

From the point of view of nutrient management (Headley et al. 1988), it is unprofitable for the plant to keep alive stems that are not able to survive. The control L. annotinum patch did not show as large changes of stem range as in a clump of trees left on the clearcutting. Only a slight increase in the occupied area, which resulted from the fact that new stems appeared was observed.

According to our observations from other lycopodium stands (unpublished data), we can assume that vertical stems live more than 5 years and die after this time. During this process, the new stems are growing up and compensating losses - but not in the same place where dead stems had already grown. However, this assumption is based on results obtained for lycopodium stands localised in commercial forests - not in old-growth forests.

The lack of stress factor does not cause accelerated wither of older stems (as our 5-year research showed). Due to this, L. annotinum has spread beyond the delineated study square according to the tactic of 'seeker' (Callaghan et al. 1988b). On the first stand, in a clump of trees, this phenomenon was not reported. Only drying out of clubmoss, stems and other underground components were observed. Smaller vitality of $L$. annotinum in a clump of trees manifested itself in smaller average length of stem increments, which is likely to be associated with the change of microclimate. Stems growing on the south side of the clump were, especially exposed to strong insolation and water shortages. In this part of the clump, systematic dying of stems was reported. The increment of stems in the north, more shaded part of the clump was higher, but it was not as high as increments of stems from the control stand deep in the forest.

On the basis of the study, it can be concluded that the higher humidity is an important factor for the survival of $L$ annotinum population, which prefers shade and moist habitats (Rutkowski 2004; Piękoś-Mirkowa and Mirek 2003; Szafer 1988). Good evidence of this is a clubmoss patch on the border of the clear-cutting (third stand), which despite the stress factors, was not as much damaged as the patch on the clear-cutting (Śliwińska-Wyrzychowska and Bogdanowicz 2012). The plants were protected from excessive loss of water by higher soil moisture, smoothing, at least in part, an adverse effect of increased insolation on stems. Mineral nitrogen compounds are subsidised in Lycopodium polycormon (Headley 1988). Availability of these compounds in the soil also effects on the size of the lycopodium patch. The results of our research showed that the mineral nitrogen compounds value was very similar for all stands. Thus, in this case, availability of mineral nitrogen compounds had no significant effect on the size of the observed Lycopodium annotinum stands.

The area of clump of trees, can affect intensity of microhabitat changes inside of it. The impact of 
adjacent open space increases in the area of forest border (Sławski 2000). Clump of trees can be recognised as border of the forest but without inner part. In smaller clumps of trees, microhabitat changes can be stronger than in bigger ones due to unfavourable ratio between the border length and the area of the clump. Mitigation of microhabitat changes in clump of trees may occur only if the distance from clump to adjacent woodland is short. In our research, the clump of trees was too far from nearest woodland border, so the canopy of adjacent woodland could not shadow and protect the lycopodium patch from intense insolation. Therefore, only the density of canopy and understory of the clump may positively affect survival ability of the $L$. annotinum patch.

\section{Conclusions}

In our research, the clumps of trees left on the clearcutting may be a place of $L$. annotinum patches survival during forestry works conducted in the forests. Changing microclimate conditions within the clump of trees on the clear-cutting, in particular, the increased insolation, results in a decrease of the area occupied by clubmoss stems, which is a result of a significant shortening of increments and wither of stems. The effectiveness of clumps, as places of clubmoss survival, depends on the humidity of soil and probably better developed understory.

\section{References}

Callaghan T.V., Svensson B.M., Headley A. 1986a. The modular growth of Lycopodium annotinum. Fern gazette, 13 (2), 65-76.

Callaghan T.V., Headley A.D,. Svensson B.M., Lixian Li., Lee J., Lindley D.K. 1986b. Modular growth and function in the vascular cryptogam Lycopodium annotinum. Proceedings of the Royal Society of London, 228, 195-206.

Ellenberg H., Weber H.E., Dull R., Wirth V., Werner W., Paulisen D. 1991. Zeigerwerte von Pflanzen in Mitteleuropa [Indicator values of plants in Central Europe]. Scripta Geobotanica 18, Verlag Erich Goltze KG, Göttingen.
Faliński J.B. 1966. Próba określenia zniekształceń fitocenozy. System faz degeneracyjnych zbiorowisk roślinnych [An attempt to determine the distortion of phytocoenosis. The degenerative phases of plant communities]. Dyskusje fitosocjologiczne (3). Ekologia Polska, 12 (1), 31-42.

Gorzelak P. 2009. Nowe stanowisko widlicza spłaszczonego Diphasiastrum complanatum L. (Lycopodiaceae) na Dolnym Śląsku i możliwości jego ochrony z punktu widzenia leśnika [The new stand of $D i$ phasiastrum complanatum L. (Lycopodiaceae) in Lower Silesia and the possibilities of its protection from the standpoint of the forester]. Acta Botanica Silesiaca, 4, 125-133.

Grochowski W. 1956. Chrońmy widłaki [Let's protect Lycopods]. Państwowa Rada Ochrony Przyrody, PWN, Warszawa.

Headley A.D., Callaghan T.V., Lee J.A. 1988. Phosphate and nitrate movement in the clonal plants Lycopodium annotinum L. and Diphasiastrum complanatum (L.) Holub. New Phytologist, 110 (4), 487-495. DOI: 10.1111/j.1469-8137.1988.tb00287.x

Kimsa T. 1996. Liczby wskaźnikowe flory Polski (oparte na danych Ellenberga, Franka and Klotza i Zarzyckiego) wraz z synonimami (według Jasiewicz) [Ecological indicator values of vascular plants of Poland - with synonyms]. Uniwersytet Śląski, Katowice.

Krukowski M. 2000. Rozmieszczenie widłakowych (Lycophytina) w piętrze subalpejskim Karkonoskiego Parku Narodowego [Distribution of Lycophytina species in subalpine belt of the Karkonoski national park]. Opera Corcontica, 37, 251-258.

Kurowski J.K. 2004. La dégénération et régénération des phytocenoses forestières: l'exemple de la Pologne Centrale. Natura Mosana, 57 (3), 57-76.

Łaska G. 2001. The disturbance and vegetation dynamics: a review and an alternative framework. Plant Ecology, 157, 77-99.

Obidziński A. 2001. Zaburzenia jako element dynamiki lasu [Disorders as part of forest dynamics]. Sylwan, 5, 51-59.

Olaczek R. 1972. Formy antropogenicznej degeneracji leśnych zbiorowisk roślinnych w krajobrazie rolniczym Polski niżowej [Anthropogenic degeneration forms of the forest plant communities in agricul- 
tural landscape of Polish Lowland]. Wydawnictwo Uniwersytetu Łódzkiego, Łódź.

Operaty Leśne Nadleśnictwo Złoty Potok 1.01.199631.12.2005 r. [Report of Złoty Potok Forest Division].

Piękoś-Mirkowa H., Mirek Z. 2003. Flora Polski. Atlas Roślin Chronionych [Atlas of Polish Protected Plants]. Wydawnictwo Multico, Warszawa.

Rozporządzenie Ministra Środowiska z dnia 16 października 2014 roku w sprawie ochrony gatunkowej roślin [The Minister of Environment Regulation on 16 October 2014 on the species of plants being under protection].

Rutkowski L. 2004. Klucz do oznaczania roślin naczyniowych Polski niżowej [The key to the determination of Polish lowland vascular plants]. Wydawnictwo Naukowe PWN, Warszawa.

Sławski M. 2006. Co możemy zyskać pozostawiając kępy starodrzewu na zrębach zupełnych? [What can we gain leaveing tree clasters on clearcut areas?]. Studia $i$ Materiaty Centrum Edukacji Przyrodniczo-Leśnej, 8 (1), 45-56.
Sokołowski A. 2004. Lasy Puszczy Białowieskiej [Woods of the Białowieża Forest]. CILP, Warszawa. Sokołowski A., Paluch R. 2006. Wpływ zrębu zupełnego i sztucznego odnowienia sosną na skład roślinności boru świeżego w Puszczy Białowieskiej [The effect of clearcutting and artificial regeneration with pine on species composition of fresh coniferous stands in the Białowieża Primeval Forest]. Sylwan, 10, 13-18.

Svennson B.M., Callaghan T.V. 1988a. Small-scale vegetation pattern related to the growth of Lycopodium annotinum and variations in its micro-environment. Vegetatio, 76, 167-177.

Svennson B.M., Callaghan T.V. 1988b. Apical dominance and the simulations of metapopulation dynamics in Lycopodium annotinum. Oikos, 51, 331-342.

Szafer W., Kulczyński S., Pawłowski B. 1988. Rośliny Polskie [Flora of Poland]. PWN, Warszawa.

Śliwińska-Wyrzychowska A., Bogdanowicz M. 2012. Selected aspects of Lycopodium annotinum L. sporulation. Ecological Questions, 16, 51-58. 